\title{
Blended Learning as an Effort to Improve the Quality of Learning at Universitas Negeri Semarang
}

\author{
Niam Wahzudik \\ Department of Curriculum and Educational Technology \\ Universitas Negeri Semarang, Indonesia \\ niam.wahzudik@mail.unnes.ac.id
}

\begin{abstract}
The current learning approach paradigm places students as subjects as well as learning objects. It is undeniable that the lecture method cannot be left out of the learning process in higher education. The potential of information and communication technology (ICT) infrastructure in Unnes has huge potential to be utilized as the main supporting means of learning. Many students have smartphone devices that students normally use to communicate with social networks. Departing from the above phenomena, it is important for researchers to implement a learning model that integrates lecture methods, while integrating and utilizing information and communication technology tools. This study aims to determine the blended learning method as an alternative to improving the quality of learning in school management courses. The research method used in this study is the Action Research method. The sample of this study were students who were taking the School Management course at Unnes. Retrieval of data using observation techniques, interviews and document studies. The stages of this research include the stages of planning, implementation, observation and reflection. The implementation of blended learning can be an alternative to improving the quality of learning in school management courses, because $62 \%$ of students said it was effective, $36 \%$ said it was quite effective and $2 \%$ said it was ineffective, and the website (edmodo) was practical for students to operate.
\end{abstract}

Keywords: blended learning, learning quality, school management

\section{INTRODUCTION}

The potential of information and communication technology infrastructure in Unnes has enormous potential to be utilized as the main supporting means of learning. Now it is not uncommon for students who already have a smartphone device that students normally use to communicate with social networks. The internet network can be accessed by students at any time. This if used wisely will provide more value for the progress of learning at this university. One learning model that matches the learning conditions of school management in Unnes is the Blended Learning model. Blended learning is learning that combines lecture learning models with internet-based learning models. Blended learning model has not been widely applied at Unnes. Blended learning does not replace face-to-face learning or lectures with online learning. But both can be done.

Blended learning can also empower social networking media for learning. This social network is very familiar among students. For that it is not wrong if blended learning applies social media-based learning. Students and lecturers can discuss each other outside classroom learning which is often limited by the normal learning time that has been scheduled. Blended learning is in line with the spirit of conservation that is carried out by Semarang State University as a Conservation University because by integrating information and communication technology in its learning it can save paperless use. The term Blended Learning (BL) has been used by educational institutions, especially universities. However, there are still many people who feel confused about the term. Many people ask when they hear about BL: What is being Blended? Although there are some differences that define
BL, many definitions have many similarities or use a common term, namely the word combining.

According to Graham (2019) BL has two types of learning environments, namely there is a traditional faceto-face learning environment (traditional face to face learning environment) that is still used around rural areas; and a distributed learning environment that has begun to develop along with new technologies that allow expansion to distribute communication and interaction. Departing from the above phenomena, it is important for researchers to apply blended learning models that are able to integrate all the potentials of lecturers, students and universities. Learning that integrates lecture methods, while integrating and utilizing information and communication technology tools. So, the quality of learning in school management courses is getting better, because besides integrating internet technology it also makes students have the independence of learning. In the long-term educational students as, prospective educators are more competent when applying their knowledge in schools. The formulation of the problem of this research is how is the blended learning method as an alternative to improving the quality of school management learning in Unnes? Whereas the aim of this study is to find out Blended Learning as an alternative to improving the quality of learning management in Unnes.

\section{METHOD}

The research method used in this study is the Action Research method. The sample of this study is lecturers supporting school management courses and prospective educator students who are currently taking courses in School Management in Unnes. Retrieval of 
data using questionnaire techniques, observation, interviews and study documents learning tools (Gunawan, 2017). The stages of this research include the stages of the activities of taking data on the description and learning constraints of school management that are applied in Unnes. Followed by a trial run the application of Blended Learning which includes stages of planning, implementation, observation and reflection. Data analysis techniques using qualitative analysis.

\section{Results And Discussion}

The direction of this study is to determine the usefulness, success of the blended learning method in improving the quality of school management learning in Semarang State University. In the application process the researcher uses action research which includes the stages of planning, implementation, observation (observation) and reflection. In the planning stage researchers have identified the problem of school management learning that is not yet even student activity during face-to-face learning and diverse student motivation. From the identification process, the researcher found the root of the problem why the problem arises in school management learning.

Researchers analyze the causes of the problem, including: (1) monotonous learning because in general lectures are conducted using the lecture, discussion, and classroom presentation methods; (2) class position or the same seat from the beginning of the lecture to completion; (3) lack of textbooks and learning media; (4) Internet facilities have not been used maximally yet; (5) various characters and backgrounds of students. From the planning stage supported by the process of identifying problems and their causes, the researchers finally took an alternative solution to address these problems by applying the blended learning method of learning in school management.

At the implementation stage of the blended learning method in school management learning begins with the preparation of a semester learning plan (RPS), registration of an account on edmodo, socialization to students related to how to attend online lectures on edmodo, uploading material, media, assignments, quizzes and midterm exams at edmodo, and midterm corrections. The observation stage (observation) of the application of the blended learning method has revealed information. During the face-to-face learning method of lecturing and discussion, positive activities were carried out by students, but activeness was not yet apparent in the majority of students.

Classes are divided into 8 groups and each group arranges papers and media presentations to be discussed in class face to face. Problems that arise in the identification of research problems are still found, namely the activeness of students to participate or active discussion in class looks to simply abort obligations, meaning that the process of discussion is not deep enough, less touches on the substance of lectures and challenges students to think critically (Arifin, 2013; Garrison \& Vaughan, 2008). Sometimes the questions presented also do not touch the substance of the material in depth. Likewise, the group that was the source of the discussion, lacked preparation, it still seemed the group was not able to explain the discussion material properly, the ability to deliver the material for the delay in uploading paper or media on edmodo.

At the time of online learning at Edmodo in the initial implementation of students enrolling in the school management group, not all students directly managed to register. This is due to some students who for the firsttime use Edmodo, do not have their own laptops or computers. Another thing that was also found at the beginning of the application of online learning and was still related to the success of students enrolling in edmodo online learning, namely the code group as a key to being able to join a group in online classes was periodically changed automatically by the system. So, students who are late registering for online lecture groups at Edmodo certainly experience difficulties because the group code has been locked.

At first the discussion activities in Edmodo's online class were less attractive to students. Gradually, every material or case study material is followed by students and is actively discussing online. Students ask each other questions, have active opinions. This is what is expected by researchers of the online learning process. Students who initially tended to be passive in class, are now more actively participating in online learning discussions. The lecturer sees this by monitoring the discussion material or case studies that are replayed by students.

In the process of doing midterm exams deliberately conceptualized online in general, it runs well in accordance with the rules of doing mid-term exam online. But still found there are still some obstacles and weaknesses. Based on the results of focus group discussions with students, it is known that several obstacles faced by students when taking online midterm exams are: (1) students are not accustomed to working online because midterm exams are usually done on paper; (2) problems with access or an unstable internet network so that sometimes connections are lost and as a result student work is not saved; (3) time management problems. There are still students who pay less attention to the work on midterm examinations, as a result, not all questions are done but the time is up; (4) found students who work not according to place. The point is that students working on midterm exams are not edmodo but with word processing applications then sent to the lecturer email.

The final process in the observation stage is knowing students' responses to school management learning with the blended learning method that has been implemented. Student responses to the blended learning method applied by lecturers in school management learning found that $56 \%$ of students stated that the blended learning method applied was good, $44 \%$ of students stated that it was good enough. The next question asked to students about the attractiveness of the edmodo school management website that is used for student learning is known that $68 \%$ of respondents answered interestingly, 30\% answered quite interesting and 2\% answered unattractive.

The level of practicality or ease of use of the Edmodo website to support school management learning, students answered $48 \%$ practically, $50 \%$ answered quite 
practical and 2\% students answered impractical. When asked the question of school management learning by combining effective lecture and online learning methods to increase student knowledge and competence in school management material, $62 \%$ of students answered effectively, $36 \%$ answered quite effectively and $2 \%$ answered ineffectively.

The fourth or final step in action research is reflection. Although in general the method of blended learning can improve the quality of school management learning, researchers feel that there is something that is quite disturbing in the success of this method. Among them First, students are not accustomed to online learning so students do not yet have the habit to be active in discussion activities or study material uploaded by lecturers or discussion groups. Students tend to be active if there are commands or instructions from lecturers to do assignments or quizzes online only. Second, not all students are active in online discussions on Edmodo. This is indeed difficult to achieve, because it can be influenced by students' motivation and learning needs. Third, the lecturer finds it difficult to control or supervise students when they take their final semester exam online. More supervision is needed to ensure that students work on midterm questions honestly.

Fourth, blended learning in school management courses requires the support of adequate facilities and facilities, for example a stable and good internet network connection, so that it does not hamper the online learning process (Trianto, 2010). Fifth, a variety of learning media is needed in delivering learning messages online, for example utilizing video or case studies that are the results of coverage or news media related to school management materials so that students are accustomed to think critically in dealing with school management issues with the correct theoretical basis.

\section{Conclusion}

The stages of this research include the stages of planning, implementation, observation and reflection. The implementation of blended learning can be an alternative to improving the quality of learning in school management courses, because $62 \%$ of students said it was effective, $36 \%$ said it was quite effective and $2 \%$ said it was ineffective, and the website (edmodo) was practical for students to operate.

\section{REFERENCES}

[1] Arifin, Z. 2013. Evaluasi Pembelajaran Prinsip, Teknik, Prosedur. Bandung: Remaja Rosdakarya

[2] Garrison, D. R., \& Vaughan, N. D. 2008. Blended Learning in Higher Education Framework, Principles, and Guidelines. San Fransisco: John Willey \& Sons, Inc.

[3] Graham, C. R. 2019. Blended Learning Systems. Retrieved 2 July 2019, from http://media.wiley.com/product_data /excerpt/86/07879775/0787977586.pdf.

[4] Gunawan, I. 2017. Pengantar Statistika Inferensial. Jakarta: Rajawali Pers.

[5] Trianto. 2010. Mendesain Model Pembelajaran InovatifProgresif. Jakarta: Kencana. 